\title{
A Review of Foreign Language Teachers' Assessment Literacy
}

\section{Emine PEHLIVAN ŞiŞMAN*}

Kağan BÜYÜKKARCI ${ }^{* *}$

\begin{abstract}
This study aims to review studies about foreign / second language teachers' language assessment literacy (LAL) from 1987 to 2019. Within the scope of this study, 82 research studies and articles are investigated in the national and international spheres. Perceptions of assessment literacy are unpacked to find out language teachers' background and needs in LAL. Subtopics are determined to categorize the research studies as assessment courses, teachers' knowledge base in language assessment, their beliefs and practices in language assessment, their training needs in assessment, professional development in LAL, perceptions in LAL, and effect of LAL and curriculum on exam preparation. This review article indicates the general view on EFL teachers' LAL level and makes suggestions in developing language assessment literacy.
\end{abstract}

Keywords: Language, assessment, assessment literacy, foreign language teaching

\footnotetext{
* Orcid id: http://orcid.org/0000-0002-7793-5918, YL Öğrencisi, Süleyman Demirel Üniversitesi, Eğitim Fakültesi, Yabancı Diller Eğitimi Bölümü, İngiliz Dili Eğitimi, emine.ma.sdu@gmail.com ** Orcid id: http://orcid.org/0000-0002-7365-0210, Dr. Öğr. Üyesi, Süleyman Demirel Üniversitesi, Eğitim Fakültesi, Yabancı Diller Eğitimi Bölümü, İngiliz Dili Eğitimi, kaganbuyukkarci@sdu.edu.tr
} 


\section{INTRODUCTION}

Assessment literacy is defined as a 'sine qua non for today's competent educator '(Popham, 2009: 4), the didactic knowledge a teacher need to have and an important component of teacher cognition (Borg, 2006; Darling-Hammond, 2008; Schulman, 1987). Also, Inbar-Lourie (2008) defines it as "body of knowledge and research grounded in theory and epistemological beliefs and connected to other bodies of knowledge in education, linguistics, and applied linguistics" (p. 396). To support and to confirm students' achievement, teachers need to collect true evidence of students' knowledge depending on the context (Stiggins, 2014). There is no doubt that assessment literacy is a prerequisite for being a teacher, foreign/ second language teachers in particular. If teachers cannot measure what they teach effectively, they would not be able to help students develop themselves.

In the last decades, language assessment literacy (LAL) has been viewed as one of the fundamental competencies of a language teacher. Their perceptions of good assessment practices and a good command of major concepts in assessment have a crucial role in high-quality education. In spite of the fact that researches in language testing and assessment (LTA) have improved education in teaching English as a foreign language (EFL) (Cheng, Rogers, \& Hu, 2004, López \& Bernal, 2009, Tsagari \& Vogt, 2017), language teachers need to keep themselves up to date with educational reforms to enhance their assessment literacy.

LAL has a crucial role in the qualification of teaching-related practices and decisionmaking processes about language achievement. Teachers need to know how to use assessment concepts in improving, applying and analyzing assessment procedures and results. They should be able to criticize their own assessment practices with regard to purpose, context and many other aspects of assessment. That's why training teachers about assessment should be given importance in English Language Teaching departments of universities. Unfortunately, many pre-service teachers state that these courses are mostly related with the techniques of testing and evaluation and the practicalities of assessment are neglected (Jin, 2010; Jeong, 2013; Lam, 2015). In fact, practicing theoretical knowledge is quite significant to help them measure their students in real world. Increasing student teachers' assessment literacy should be a priority to provide good education.

Research helps identifying actual problems and needs in education. Then, stakeholders can make use of these data to improve education. In this respect, this article reviews research studies on LAL and analyzes how it is conceptualized and approached within years. By this way, necessary steps can be taken to improve the quality of education through renewed assessment practices. A general suggestion on how to improve assessment literacy of EFL teachers is offered. 


\section{LITERATURE REVIEW}

In this study, compilation method was used as a research method. The compilation method allows the analysis of the studies carried out in a specific field and subject, thus the information in the literature is reproduced by synthesis. The aim of the compilation studies that review the existing studies in the literature and combine old and new interpretations in the light of reviewing or reveal completely new interpretations is to summarize the thoughts and approaches of other researchers and to create a new synthesis (Herdman, 2006).

In this study it is aimed to demonstrate the researches performed in order to develop vocational and technical secondary education which is being practised in today's Turkey as well as the historical development of vocational and technical education in Turkey generally. In this context the development of vocational and technical education in Turkey is attempted to be explained in the historical process, and studies have been tried to be summarized by scanning the literature.

\section{What is assessment?}

Since 'evaluation', 'assessment' and 'testing' are interchangeably used terms, detailed definition of each is necessary to be more precise. Assessment is "the process of gathering, interpreting, recording and using information about pupils' responses to educational tasks." (Lambert \& Lines, 2000, p. 4). Also, it refers to "a systematic procedure for eliciting test and non-test data for the purpose of making inferences or claims about certain language-related characteristics of an individual" (Purpura, 2016, p. 191). Coombe, Folse \& Hubley (2007) summarizes the terms as "Evaluation includes the whole course or program, and information is collected from many sources, including the learner. While assessment is related to the learner and his or her achievements and testing is part of assessment, and it measures learners' achievement".

\section{Definitions of LAL}

Assessment literacy is defined as "an individual's understandings of the fundamental assessment concepts and procedures deemed likely to influence educational decisions" (Popham, 2011, p. 267). As cited in DeLuca \& Klinger (2010), Stiggins (2002) and Volante \& Fazio (2007) described assessment literacy as "the understanding and appropriate use of assessment practices along with the knowledge of the theoretical and philosophical underpinnings in the measurement of students' learning". 


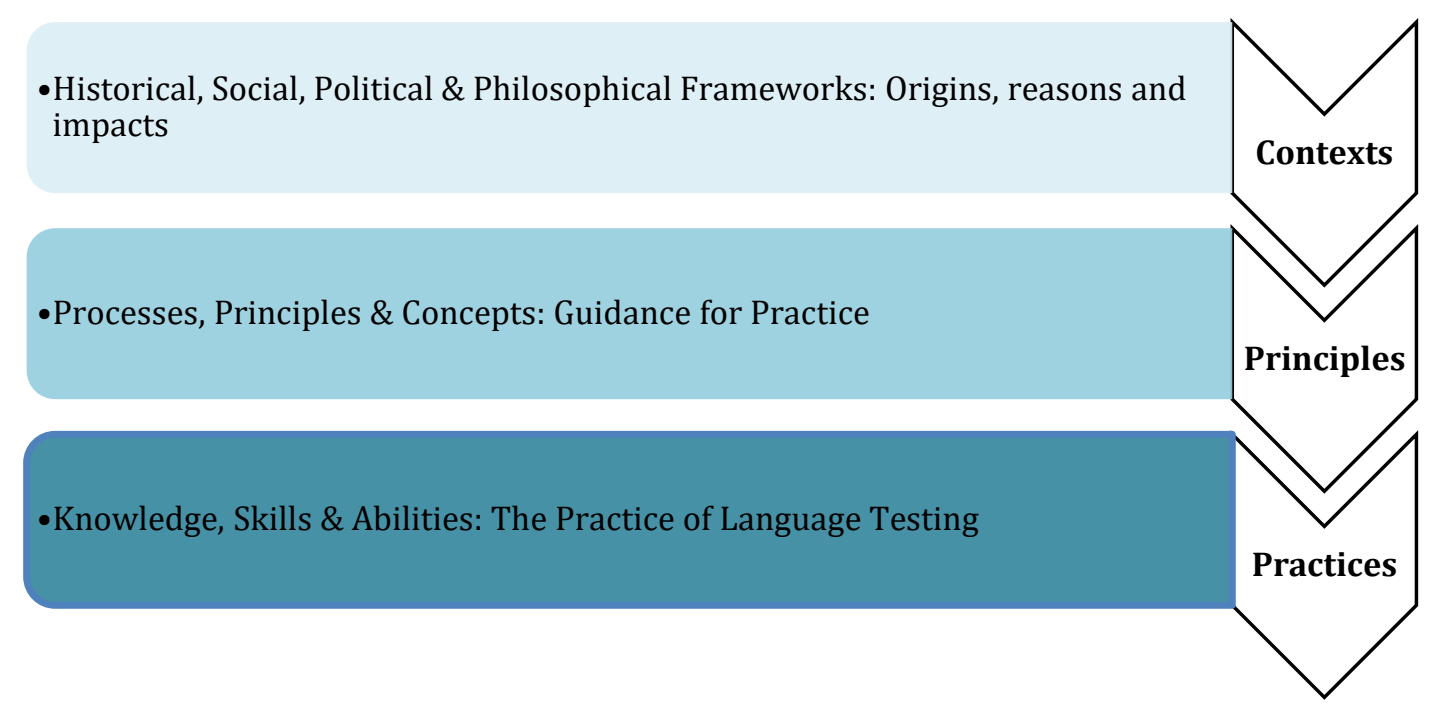

Figure 1. An expanded definition of assessment literacy

Furthermore, studying with participants from different continents, Fulcher (2012) introduced four factors in the concept of assessment literacy as "test design and development", "large-scale standardized testing", "classroom testing and washback", and "validity and reliability". According to the collected data, Fulcher tried to conceptualize the assessment literacy from a broad perspective by elaborating on the practices, principles and contexts of language assessment (figure 1). Based on the findings, Fulcher (2012) came up with a definition of assessment literacy as follow:

The knowledge, skills and abilities required to design, develop, maintain or evaluate, large-scale standardized and/or classroom based tests, familiarity with test processes, and awareness of principles and concepts that guide and underpin practice, including ethics and codes of practice and the ability to evaluate the role and impact of testing on society, institutions, and individuals (pp. 113-132).

On the other hand, Price et al. (2012) tried to provide a broad definition of assessment literacy:

...an appreciation of the purpose and processes of assessment, which enables one to engage deeply with assessment standards, to make a choice about which skill or which area of knowledge to apply, to appreciate which are/are not appropriate to a particular task, and why ... assessment literacy are enablers (thresholds): they enable one to go beyond a grasp of basic principles towards a deeper understanding and engagement (p.10).

According to these definitions, it can be inferred that assessment literacy is the ability to design, apply and evaluate appropriate exams for learners based on theoretical knowledge, skills and principles. Being aware of the assessment concepts and procedures also affects educational decisions importantly. 
Besides assessment literacy, LAL is defined by Taylor (2009) as "the level of knowledge, skills and understanding of assessment principles and practice that is increasingly required by other test stakeholder groups, depending on their needs and contexts." (p.24). According to Malone (2013) LAL is a language teacher's knowledge of testing definitions and using this knowledge in class for assessment. Vogt \& Tsagari (2014) attempted to define language assessment literacy as the ability to design, develop and critically evaluate language tests and other assessment procedures, as well as the ability to monitor, grade and score assessments on the basis of theoretical knowledge. In addition, Inbar-Lourie (2017) specified that LAL necessitates more competencies than assessment literacy does. In fact, it is blending assessment literacy skills with languagespecific skills.
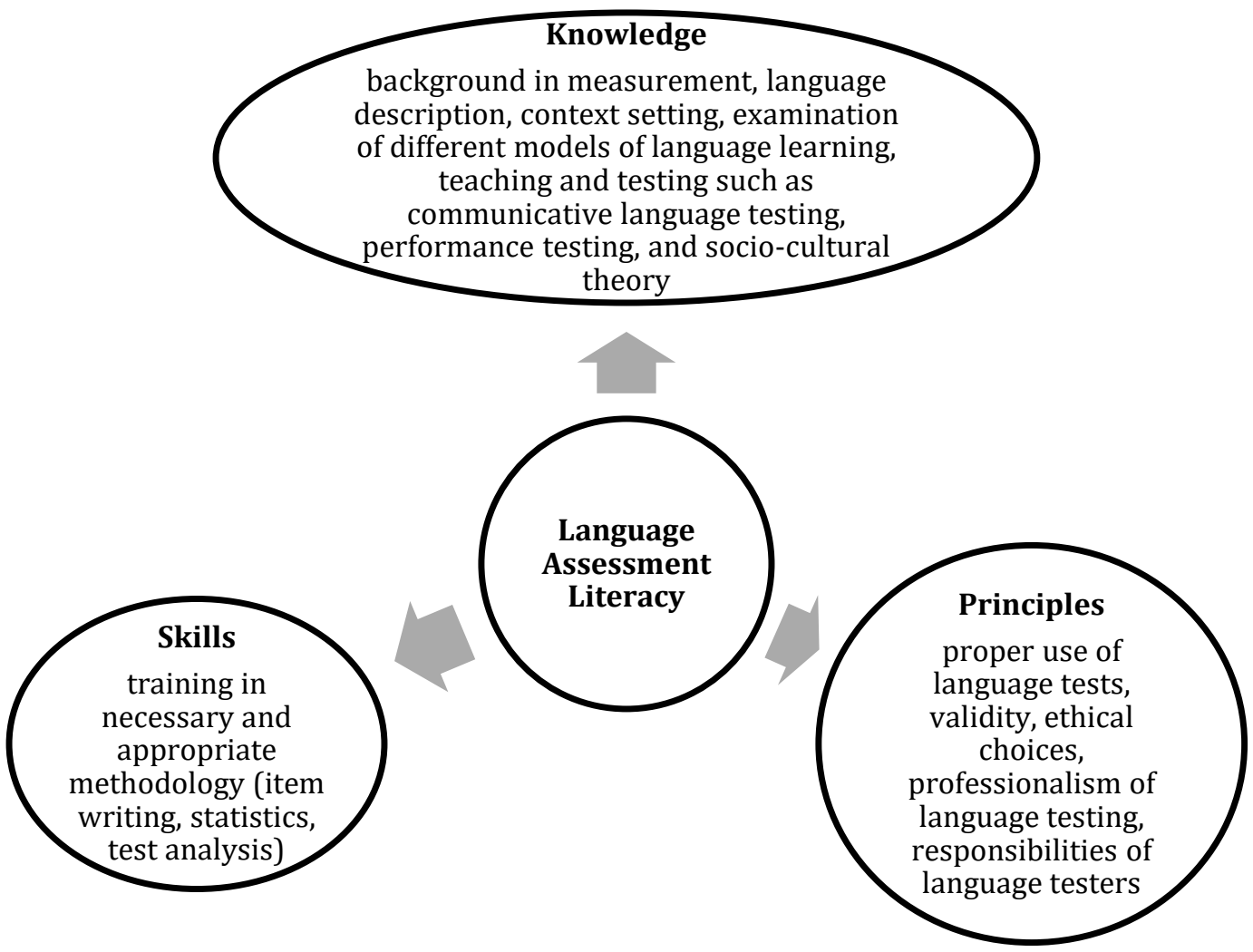

Figure 2. A Core List of Language Assessment Literacy Dimensions: Knowledge, Skills \& Principles (Davies, 2008, p. 328).

In Figure 2, Davies (2008) describes LAL in three essential components: skills, knowledge, and principles. He refers to basic testing expertise in skills section, awareness about measurement and about language is related with knowledge, and language assessment principles includes main concepts in testing such as validity and reliability. He claims that skills cannot be sustained without knowledge and states "if skills represent 'how?', then knowledge represents 'what?'” ( Davies, 2008, p. 335). To 
provide a good education, skills (practical), knowledge (descriptive) and principles (theoretical) need to be adjusted well.

Briefly, it can be said that an assessment literate person who is aware of the fundamental assessment concepts and procedures have a significant effect on education. An assessment literate language teacher should be able to design, improve, monitor, evaluate, grade and analyze language tests and other assessment procedures depending on her theoretical knowledge. Skills and knowledge are not enough to make assessment valid and reliable. They should be accompanied with principles to make language assessment properly. Last, a test designer should take the impact of testing on society, institutions and individuals into consideration.

\section{INTERNATIONAL LAL STUDIES}

Language assessment literacy studies in the international sphere were demonstrated under eight interrelated categories. These are perceptions in language assessment literacy, assessment courses, teachers' knowledge base in language assessment, their beliefs and practices in assessment, training needs of them in assessment, professional development in LAL and teachers' perceptions in LAL. Mostly, the focus of these studies was on language teachers' training needs in assessment owing to inadequate pre-service training.

\section{Assessment courses}

There are number of research studies about the efficacy of assessment courses in preservice language teaching programs. For instance, Brown and Bailey (1996 \& 2008) focused on the basic characteristics of language assessment courses and their change. According to the findings, pre-service language teachers became more competent in bridging the gap between theory and practice by gaining experience. Therefore, most of the assessment literacy research studies around the world showed that pre-service language teaching programs should offer more training in language assessment (Cheng, Rogers \& Hu, 2004, Frodden, Restrepo \& Maturana, 2004; Arias \& Maturana,2005; Volante \& Fazio, 2007, López \& Bernal, 2009, Díaz, Alarcón, \& Ortiz, 2012, Muñoz, Palacio \& Escobar, 2012). Most of these studies came up with suggestions like improving the validity, reliability, and fairness of language assessment practices to develop the quality of teaching and learning.

In addition, Jin (2010) concluded that while validity, reliability, item writing, item facility, item discrimination, score interpretation and testing four skills were taught very well, practicing the theory was neglected. Similarly, Jeong (2013) indicated that course instructors with language assessment training had a tendency to focus on theoretical aspects of language assessment. On the other hand, teacher education institutes' ignorance on the social aspects of language assessment such as validity and fairness made pre-service language teachers incompetent in language assessment. Thus, imbalance between language assessment courses at universities and assessment practices at schools was inevitable (Lam, 2015). Moreover, language teachers without 
any background in assessment concentrated on the practical aspects of language assessment in their courses, which affected their choices of course books as well.

Another study by Muhammad and Bardakçı (2019) aimed to explore Iraqi EFL teachers' assessment literacy level. Classroom Assessment Literacy Inventory (Mertler, 2003) was used as research instrument. Results revealed that Iraqi EFL teachers' level of assessment knowledge is the lowest among all the previous research in the field (Campbell, Murphy, \& Holt, 2002; Davidheiser, 2013; Perry, 2013; Plake, 1993; Plake, Impara, \& Fager, 1993; Yamtim \& Wongwanich, 2013). Teachers were found to be weak in recognizing inappropriate assessment methods and uses of assessment information. They ranked the highest in using assessment results to make educational decisions. As a conclusion, he indicated that educational reforms need to be done according to the needs of Iraqi EFL teachers to provide them with sufficient background in assessment.

\section{Teachers' knowledge base in language assessment}

Another focus of the studies was on language teachers' background knowledge in assessment and its impact on their assessment practices. López and Bernal (2009, as cited in Giraldo, 2019) found out that language teachers with assessment training used assessment practices to improve teaching and learning, while those with no training applied it only to obtain grades. In addition, the teachers in this research mostly preferred summative instead of formative methods.

Kiomrs, Abdolmehdi and Naser (2011) inferred that Iranian EFL teachers had low level of LAL since they were only familiar with standardized tests, and they assumed that such tests are the best way to assess learners' language skills. Also, this study implicated that the participants could not manage to get over the negative effects of the standardized tests. Similarly, in Malaysia, Talib, Kamsah, Ghafar, Zakaria and Naim (2013) revealed that language teachers were insufficient to apply the fundamental concepts of language assessment due to the lack of language assessment literacy.

On the other hand, it has been indicated that teachers with an appropriate level of LAL can connect instruction and assessment, criticize large-scale tests, and design and choose from an available repertoire of assessments (Herrera \& Macías, 2015).

Another study by Leaph, Channy and Chan (2015) showed that the Cambodian ELT instructors applied standardized tests improperly in their assessment practices for their low level of LAL. The reason behind this was that many instructors were oblivious of standardized tests, some did not even take such tests and they could not differentiate between the aim of classroom-based assessment and the purpose of the standardized tests. Likewise, in their study, Xu and Brown (2017) mentioned that the Chinese EFL instructors at Chinese universities had a low level of LAL in consequence of the absence of assessment policies and professional standards, insufficient pre-service and in-service training and the lack of assessment literacy as an employment requirement.

\section{Teachers' beliefs and practices in language assessment}

There are some studies focusing particularly on language teachers' beliefs and practices in language assessment. According to Rogers, Cheng and $\mathrm{Hu}$ (2007), language 
assessment was found beneficial in terms of improving language teachers' instruction and their students' learning. However, there was a gap between the participants' assessment practices and beliefs (Rogers et al., 2007). On one hand, they supported using non-traditional assessment in language assessment. On the other hand, they applied pen-and-paper tests, a traditional assessment method. Similarly, Shohamy and her colleagues (2008) found out that language teachers supported teaching pragmatics, metaphor, culture and using alternative and diagnostic assessment in advanced language classes. Yet, the participants preferred using summative assessment instead of formative and diagnostic assessment.

In a different study by Munoz, Palacio and Escobar (2012), the participants believed that assessment could improve teaching and learning and support performance evaluation of an institution and it might be used for formative purposes. Contrary to their beliefs, the participants did not make use of their assessment results and did not applied for formative purposes (Munoz et al., 2012). These conclusions were compatible with the abovementioned studies by Rogers et al. (2007) and Shohamy et al. (2008). In general, research results revealed that the reasons behind the difference between assessment beliefs and practices were class size, limited time, standardized tests, work overload (Rogers et al., 2007) and teaching context, experience and lack of training (Shohamy et al., 2008). Nevertheless, another study proved that language teachers followed their assessment beliefs in their assessment practices (Chan, 2008). In this study, the participants accepted assessment as a part of their responsibility. Not only the alternative assessment, but also multiple assessments were applied to enhance achievement in language education. Alternative assessment was mentioned to be the most useful. Meanwhile, Chan (2008) acknowledged that work overload and timeconsuming activities affected his participants' assessment practices.

Furthermore, the research findings in Jannati's (2015) study indicated that Iranian EFL teachers had the same assessment beliefs with the other participants in the previous studies. Jannati (2015) also investigated the participants' knowledge about the basic terms of language assessment. Even though they were familiar with the fundamentals of language assessment, they did not pay attention on making their exams valid, fair and reliable. Also, course objectives, curriculum, students' language proficiency and their ages were other influencing factors in assessment activities.

In another study, Hidri (2015) focused on the relationship between the EFL teachers' LAL and their perceptions of assessment in Tunisia. His research showed that development, responsibility and inapplicability affected the participants' language assessment literacy. The participants found assessment impractical because they found it ineffective for students' business life. Hakim also (2015) investigated the EFL teachers' ideology of assessment. She found out that the participants' perceptions of assessment concepts in their assessment practices were in line with their experiences. The more experience a language teacher has, the more assessment concepts are used in their assessment practices. 
Besides, Yan, Zhang \& Fan (2018) investigated the effects of contextual and experiential factors in language teachers' LAL development. The results show that "educational landscape and policies", "institutional mandates", and "local instructional context" were described as the contextual factors; yet, "assessment development" and "item analysis and score use" were classified as the experiential factors (Yan, Zhang \& Fan, pp. 162165). They concluded that teachers need more training in assessment practice than in assessment theory.

A recent study by Giraldo (2019) indicated that participant language teachers followed a multi-method in their assessment practices. They tried to balance assessment and teaching, and used assessment data to improve students' learning. Moreover, they regarded a good language assessment as valid, reliable, providing constructive feedback and positive washback.

Additionally, there are some studies argued the efficacy of LAL in language teachers' instruction. According to Rea-Dickins (2006), having a high level of LAL helped language teachers utilize assessment-based dialogues in the classroom; thus, this improved students' language learning. In a similar study, Hamp-Lyons (2017) found out that a good level of LAL enables language teachers to reveal and turn learning-oriented assessment opportunities into formal tests.

In addition, language teachers can fulfill the expectations of national education by having a good level of LAL (Sellan, 2017). Sellan showed that the participant Singaporean language teachers took responsibility and expanded their assessment constructs by paying more attention to culture, widening genre perception, focusing on content knowledge and practicing high-order thinking skills and learning in real-life contexts. So, they improved their students' learning.

Last, in a project, Berry, Sheehan and Munro (2019) aimed to explore teachers' attitudes towards assessment and their assessment practices by conducting interviews, classroom observations with follow-up interviews, and focus group discussions in the United Kingdom, France, and Spain. The results showed that teachers were good at applying various assessment techniques although they felt hesitant about their knowledge on testing and assessment. The participant teachers perceived assessment negatively, yet they regarded good assessment practices as part of good teaching and being a good teacher was significant for them. The researchers claim that assessment has a great impact on the classroom. Nevertheless, sometimes it can be negative because teachers confuse assessment with testing, and testing may have a negative impact on language learning. Even though they cope with a range of assessment techniques well in class, participants did not perceive assessment as an essential part of teaching. Instead, they consider it as a synonym of 'testing' and did not think that any aspects of assessment were covered in their teacher training. In addition, teachers had a tendency on readymade activities since they were too busy and not confident to create assessment materials which means they prefer to put responsibility on an external agency. 


\section{Training needs of EFL/ ESL teachers in assessment}

Other studies aimed at identifying language teachers' training needs (Hasselgreen et al., 2004; Vogt et al., 2008; Guerin, 2010; Vogt \& Tsagari, 2014). Fulcher (2012) revealed that language teachers wanted more training in the basic concepts of LTA and expected language assessment course books to include the real-life assessment activities.

Vogt and Tsagari (2014) conducted a research study to investigate foreign language teachers' perceptions and training needs in LAL in seven countries (Cyprus, Former Yugoslavian Republic of Macedonia, Germany, Greece, Italy, Poland, and Turkey). The results showed that the majority of the language teachers had received training in language assessment at some point in their pre- or in-service teacher training. Yet, again the majority of participants reported a need for advanced training for the "receptive" and "productive skills" as well as for the "microlinguistic aspects".

Insufficient pre-service training made language teachers improve their assessment literacy while working and use assessment tools inappropriately in their classes; thus, they have negative experiences and avoid self-assessment on their assessment practices (Tsagari \& Vogt, 2017; Vogt \& Tsagari, 2014). Due to inadequate pre-service training, those teachers were not able to identify their weaknesses in assessment practices and they mostly apply to traditional forms of assessment contrary to expectations (Tsagari \& Vogt, 2017). The findings revealed that language teachers in the European countries found their pre-service training in language testing and assessment (classroom-focused testing and assessment, content and concepts, purposes of testing, and/or external tests and exams) insufficient and they looked for extra training in assessment.

\section{Professional development in LAL}

Arguable efficacy of language assessment training at the pre-service level put a spotlight on professional development (PD) for language teachers. A few studies emphasized the significance of online or face-to-face professional development programs to improve inservice language teachers' language assessment literacy (Mahapatra, 2016; Montee et al., 2013; Nier, Donovan, \& Malone, 2013; Riestenberg et al., 2010; Walters, 2010). Walters (2010) implicated that assessment standardization of governmental organizations helped language teachers profoundly evaluate themselves and meet the political expectations.

According to Riestenberg and her colleagues (2010), an online PD course provided language teachers an opportunity to get familiar with the fundamentals of assessment (e.g. validity, reliability) and use them in their courses.

Moreover, Nier et al. (2013) discovered that an online assessment course made language teachers more comfortable with assessment terms by leading to a positive change in their perception of assessment.

Further, Montee et al. (2013) found out that a short-term face-to-face professional development course on language assessment encouraged participants to be more positive in assessment practices, to combine their teaching with assessment and to deal with students in their assessment practices. 
In his study, Mahapatra (2016) demonstrated that web 2.0 tools helped language teachers improve their language assessment literacy. Therefore, professional development increased the participant language teachers' LAL by introducing basic assessment terms. In fact, they even became evaluative in their assessment practices, engage their students more in assessment and related their assessment with their teaching.

López and Bernal (2009) emphasized that prospective teachers should not be satisfied with a basic course they attend in pre-service and they need to look for more in-service training on assessment via conferences, workshops etc. This is the key to enable continuous improvement in language education.

\section{Perceptions in LAL}

In addition to these studies, other studies dealt with the meaning of language assessment literacy for language teachers and the effect of peer work on language teachers' LAL. Davies (2008) described three essential components in LAL: skills (the how-to or basic testing expertise), knowledge (information about measurement and about language), and principles (concepts underlying testing such as validity, reliability, and ethics). Inbar-Lourie (2008) defined assessment literacy as "body of knowledge and research grounded in theory and epistemological beliefs and connected to other bodies of knowledge in education, linguistics, and applied linguistics" (p. 396). Also, she emphasized that standards need to be set and there should be proficiency levels teachers need to have in the field of language testing and assessment. On the other hand, Razavipour (2014) defined LAL as having necessary skills to assess and evaluate students' language development. She also expressed that the participant language teachers mostly based their assessment literacy on their own experiences as students.

In the light of the international research findings, it can be said that pre-service assessment courses have become effective in bridging the gap between theory and practice (Brown and Bailey, 1996 \& 2008), yet there is still a need for more training (Cheng, Rogers \& Hu, 2004, Frodden, Restrepo \& Maturana, 2004; Arias \& Maturana,2005; Volante \& Fazio, 2007, López \& Bernal, 2009, Díaz, Alarcón, \& Ortiz, 2012, Muñoz, Palacio \& Escobar, 2012). Due to a lack of pre-service training in assessment, language teachers' in-service training needs were emphasized (online or face-to-face). In other terms, professional development was seen inevitable in this field. Besides, it is observed that there is discrepancy between participant language teachers' beliefs and practices in assessment in which class size and work load play significant roles. According to these studies, the effect of having low or high level of LAL on language teachers' assessment practices and on learners' improvement was also underlined (e.g. instruction, assessing ICC).

\section{LANGUAGE ASSESSMENT LITERACY STUDIES IN TURKEY}

Research studies in Turkey primarily focus on the efficacy of pre-service training on assessment (Hatipoğlu, 2010; Yetkin, 2015; Yastıbaş, 2018; Sevimel Şahin, 2019). Some studies revealed that the pre-service language assessment training is inadequate and 
incomprehensive (Büyükkarcl, 2016; Hatipoğlu, 2015b; Mede \& Atay, 2017; Öz \& Atay, 2017; Şahin, 2015). This was because of the lack of necessary time spend on assessment courses and sometimes student teachers' beliefs. Since summative assessment is in the heart of Turkish education system (Gönen \& Akbarov, 2015; Şahin, 2019), teachers are affected accordingly and few may resist in developing themselves more in other assessment types. Even though they have had enough training, some teachers observed having difficulty in applying what they had learnt because of large class size and work load.

Apart from the topics given in the international LAL studies, this part includes effects of LAL and curriculum on exam preparation. Also, 'professional development in LAL', 'perceptions in LAL' have not been studied in Turkey yet.

\section{Assessment courses}

Hatipoğlu (2010) stated that the pre-service ELT students had only one language assessment course and thought it was not enough to learn and practice the concepts of language assessment. Since they did not balance the gap between theory and practice, they could not criticize their assessment practices properly. Similarly, Hatipoğlu and Erçetin (2016) acknowledged that it is not possible to cover all of the issues and concepts of language assessment in one course. A lecturer might only help their preservice ELT teachers raise awareness on the fundamentals of assessment, but there is not enough time to practice. In another study, Hatipoğlu (2015a) revealed that the local assessment cultures and contexts and their prior assessment experiences affect preservice ELT teachers' perceptions on assessment course negatively.

Furthermore, Yastıbaş (2018) pointed out that in-service EFL teachers had a critical attitude toward assessment and evaluation. The participants claimed that they improved themselves in language assessment practices by gaining experience. Also, the researcher focused on a detail not mentioned before and found out that whereas participants graduating from faculty of education were satisfied with the training they had in assessment during pre-service years, others graduating from different faculties evaluated their training background in assessment as ineffective. The results also revealed that the participants interpreted basic assessment concepts like validity, reliability in a different way and tried to make their exams valid and reliable in their own way. He also emphasized the negative effects of factors like the number of the students and workload on in-service teachers' assessment practices.

In her study, Sevimel Şahin (2019) examined the effectiveness of 'English Language Testing and Evaluation (ELTE)' course on pre-service English language teachers' foreign language assessment literacy (FLAL) and she tried to find out assessment training needs of them. In total, 178 participants including lecturers, novice EFL teachers and preservice ELT teachers attended her study. Moreover, document analysis of ELTE course content was done. Findings revealed that most participants focused only on the notion of testing, summative assessment, the testing purposes of diagnostics and achievement, and the knowledge base of assessment literacy. Participants found ELTE course 
sufficient, but they criticized the course content being too theoretical. Also, they thought that course content was insufficient in terms of practice, integrated language testing, interpretation and evaluation skills. In terms of training needs, participants emphasized that they are lacking information about alternative assessment, testing productive skills, integrated testing, interpretation and evaluation skills, contextual issues in testing. So, the content of ELTE course is required to be revised to help pre-service English language teachers increase their LAL levels.

In contrast to these studies, Yetkin (2015) asserted that the pre-service assessment course gave student teachers an opportunity to develop their knowledge of assessment through assignments and school practicum course.

\section{Teachers' knowledge base in language assessment}

Most of the research studies conducted in Turkey demonstrated that the language assessment literacy levels of the in-service Turkish ELT teachers working at the state and private primary, secondary, high schools and preparatory departments of the state and foundation universities were low because of their background knowledge in language assessment and the quality of training they had (Büyükkarcl, 2016; Hatipoğlu, 2015b; Mede \& Atay, 2017; Öz \& Atay, 2017; Şahin, 2015). Their knowledge of assessment was measured with two different tools: "Assessment Literacy Inventory (ALI)" (Mertler \& Campbell, 2005) and "Language Testing and Assessment Questionnaire (LTAQ)" (Vogt \& Tsagari, 2014). For instance, Büyükkarcl (2016) conducted ALI and found out that foreign language teachers had a very low level of assessment literacy, and experience and post-graduate studies did not help them improve it.

Other researchers (Hatipoğlu, 2015b; Mede \& Atay, 2017) preferred using LTAQ to determine their participants' background knowledge in assessment and needs for assessment training in three components: classroom-focused language testing and assessment (LTA), purposes of testing and content and concepts of LTA (Vogt \& Tsagari, 2014). Results in general demonstrated that the in-service Turkish ELT teachers are not competent enough in language testing and assessment because of their inadequate knowledge of assessment.

\section{Teachers' beliefs and practices in language assessment}

While insufficient assessment knowledge affects the attitude of the in-service Turkish EFL teachers towards different types of assessment (Aksu Ataç, 2012), a few researchers (Büyükkarcl, 2014; Han \& Kaya, 2014; Öz, 2014) stated that the in-service Turkish EFL teachers' assessment beliefs and practices are not affected by pre-service and in-service assessment training courses. Büyükkarcı (2014) demonstrated in his small-scale mixed methods study that the in-service Turkish EFL teachers at primary schools had shown positive attitudes toward formative assessment, yet they could not apply it properly because of large class sizes and workload. Further, summative assessment influenced the in-service EFL teachers' aims in assessment and choice of question types. For instance, Öz (2014) showed in his study that the participants did not include their 
students in the assessment process and neglected assisting them in improving their weaknesses. Furthermore, Öz and Atay (2017) stated that there was a difference between the in-service Turkish EFL teachers' assessment perceptions and practices even though they knew basic classroom assessment.

Besides, Han and Kaya (2014) demonstrated that pre-service or in-service assessment training did not have an influence on Turkish ELT teachers' assessment choices, and they mostly depend on their personal assessment preferences. In addition, Gönen and Akbarov (2015) indicated that centralized assessment system, syllabi and students' educational background did not allow the in-service Turkish EFL instructors to apply their assessment beliefs.

In a recent research study, Şahin (2019) supported the previous findings by mentioning the inadequacy of language testing and assessment training in pre-service level. She acknowledged that summative assessment was given particular importance in English language testing and evaluation course (ELTEC) in Turkey and formative assessment was neglected as a testing tool. Although the pre-service EFL teachers regarded their LAL training in the ELTEC as satisfactory in general, they felt less adequate in alternative assessment tools, formative assessment, and assessing productive skills (Şahin, 2019).

\section{Training needs of EFL/ ESL teachers in assessment}

A research study by Sarıyldız (2018) showed that the preservice EFL teachers evaluated their training in different domains of language testing and assessment as insufficient and they needed further basic training. Participants emphasized their need of putting theoretical knowledge of language testing and assessment into practice during their teaching practicum.

Semiz \& Odabaş (2016) conducted a study about language assessment literacy of inservice EFL teachers. They applied LTAQ (Vogt \& Tsagari, 2014) to 48 Turkish EFL teachers who work in state schools in Trabzon, Turkey. They found out that teachers need training on using portfolio, placing students onto courses or programs, awarding final certificates, testing and assessment of integrated language skills and aspects of culture.

Another study by Ölmezer-Öztürk \& Aydın (2019) with 542 EFL teachers revealed that teachers need more training on assessing listening. Similarly, in a research study by Kavaklı \& Arslan (2019), pre-service language teachers emphasized their needs on more authentic and practical courses since they feel inadequate in preparing exams properly for their future students.

\section{Effects of LAL and curriculum on exam preparation}

Not having adequate training in assessment during pre-service years affects the inservice Turkish EFL teachers' exam preparation in a negative way. Köksal (2004) and Sarıçoban (2011) investigated the exams prepared by the in-service Turkish EFL teachers working at the state schools in their document analysis studies. Köksal (2004) indicated problems in the teachers' exams such as timing, scoring, spelling, punctuation, 
legibility, the level of students, construct validity, contextualization, instruction, content validity, washback and reliability.

On the other hand, Sarıçoban (2011) pointed out the improvement of in-service Turkish EFL teachers in their exams with regard to face validity, spelling, punctuation, instruction, timing, contextualization, scoring, legibility and reliability. However, content and construct validity, naming sections and washback were stated as problematic areas in both studies.

Besides LAL, educational changes can sometimes affect language teachers' choices in question types. Kırkgöz \& Ağçam (2012) analyzed 100 written examination papers to investigate the effects of the curriculum reforms in the question types which in-service EFL teachers preferred to use in their exams in primary education in Turkey. They stated that there is no major difference between the question types after the 2005 curriculum change. Yet, it is observed that constructed response items exceeded selected response items after 2005. Also, more pictures and illustrations were used in questions to ensure more contextualized information.

When all research findings in Turkey are taken into account, it can be indicated that there is a need for more training in pre-service level. Even if student teachers have the necessary theoretical background in language assessment, they need more course hours in pre-service to fulfill the need of practicing what they have learnt. When the exams prepared by Turkish EFL teachers in state schools were investigated (Sarıçoban, 2011; Köksal, 2004), some problematic areas such as validity, reliability and timing were detected. Besides, centralized assessment system and language teachers' prior experiences lead them not to apply appropriate assessment types. Instead of focusing on learners' improvement in assessment practices, they try to meet the needs of national education system which leads them to summative assessment everywhere.

\section{CONCLUSION AND SUGGESTIONS}

As Giraldo (2018) argued, language teachers with solid assessment knowledge are necessary for good education since they make decisions depending on assessment data. This review put a spotlight on the problematic areas and needs in language assessment and testing. In general, assessment literacy was defined as someone's perception in fundamental concepts and procedures in assessment, and the ability to apply them in class appropriately to measure learners' performance (Popham, 2011; Stiggins, 2002; Volante \& Fazio, 2007).

In the light of the international studies, assessment courses were mostly found insufficient and there was an imbalance between theory and practice. (Cheng, Rogers \& $\mathrm{Hu}, 2004$, Frodden, Restrepo \& Maturana, 2004; Arias \& Maturana,2005; Volante \& Fazio, 2007, López \& Bernal, 2009, Díaz, Alarcón, \& Ortiz, 2012, Muñoz, Palacio \& Escobar, 2012; Lam, 2015). Also, teachers' knowledge base in assessment mainly depended on standardized tests. Even though some teachers were familiar with various assessment types, they did not apply them in their courses because of time, class size 
and workload issues. They emphasized their needs about more practice in pre-service to be prepared for real classes. Interestingly, the more experienced teachers tended to use more assessment concepts in their classes than the novice ones. Furthermore, some teachers perceived assessment as a separate part of teaching and preferred using readymade tests rather than preparing themselves.

In terms of needs, most teachers lacked real-life assessment activities, assessing receptive and productive skills, and testing microlinguistic aspects. Also, in-service teachers looked for more assessment training either face-to-face or online to improve their LAL as part of their professional development. With regard to perceptions in LAL, it was perceived as the combination of skills, knowledge and principles by Davies (2008). On one hand, Inbar-Lourie (2008) regarded it as integration of theoretical knowledge, epistemological beliefs, knowledge about linguistics and applied linguistics, and standards needed to be set to define teachers' assessment literacy levels. On the other hand, Razavipour (2014) said that it is having the necessary skills in testing and assessment, and teachers mostly gained them thorough experience. Lastly, it is observed that there is discrepancy between participant language teachers' beliefs and practices in assessment in which class size and work load play significant roles.

According to the national studies, assessment courses were regarded as inadequate in practice, basic terms (e.g. reliability, validity), integrated language testing, interpretation and evaluation skills, alternative assessment, testing productive skills and contextual issues. In testing. Also, in-service Turkish EFL teachers' knowledge base was found insufficient in language testing and assessment (Büyükkarcl, 2016; Hatipoğlu, 2015b; Mede \& Atay, 2017; Öz \& Atay, 2017; Şahin, 2015; Hatipoğlu, 2015b; Mede \& Atay, 2017). Furthermore, there was a difference between the in-service Turkish EFL teachers' assessment perceptions and practices even though they knew basic classroom assessment (Öz and Atay, 2017). Gönen and Akbarov (2015) stated that in-service Turkish EFL instructors were not able to apply their assessment beliefs because of centralized assessment system, syllabi and students' educational background. Likewise, Şahin (2019) said that summative assessment was given more importance as a testing tool than formative assessment. English language teachers felt less adequate in alternative assessment tools, formative assessment, and assessing productive skills (Şahin, 2019).

With regard to the needs, teachers wanted to be trained more on applying theoretical knowledge in practice, using different domains of language testing and assessment (Sarıyıldı,2018), using portfolio, placing students onto courses or programs, awarding final certificates, testing and assessment of integrated language skills and aspects of culture (Semiz \& Odabaş, 2016), assessing listening (Ölmezer-Öztürk \& Aydın, 2018), on more authentic and practical courses (Kavaklı \& Arslan, 2019). In terms of exams, teachers' language assessment literacy level affected timing, scoring, spelling, punctuation, legibility, the level of students, construct validity, contextualization, instruction, content validity, washback and reliability (Köksal, 2004). On the other hand, Sarıçoban (2011) stated that teachers improved face validity, spelling, punctuation, 
instruction, timing, contextualization, scoring, legibility and reliability in their exams. Nevertheless, both studies revealed that teachers were not very knowledgeable about content and construct validity, naming sections and washback. Not only teachers' LAL level, but also changes in curriculum may sometimes have impacts on exams. For instance, Kırkgöz and Ağçam (2012) found out almost no major difference between the question types after the 2005 curriculum change. However, there were more constructed response items than selected response items in tests, and information was more contextualized with pictures and illustrations after 2005.

When all the research findings are taken into account, it can be said that language teachers had a low level of assessment literacy. Literature review revealed that preservice training was insufficient for language teachers to learn and conduct assessment practices, but they became better in balancing theory and practice thorough experience. Even though teachers had sufficient knowledge in assessment concepts and procedures, they mainly focused on meeting the needs of national education system so much so that it led them to apply summative assessment excessively. However, learners' improvement should be prioritized in all aspects of education. It is clear that new regulations are required to be done to improve assessment literacy of language teachers.

Regarding suggestions, educational reforms are needed in both pre-service training of language teachers and current educational environment. For pre-service teachers, more assessment courses need to be included in the curriculum of language teacher education and the content should balance theory and practice. Furthermore, self-assessment is necessary for both pre-service and in-service language teachers. With regard to the language teachers' need of using portfolio (Semiz \& Odabaş, 2018), the European Portfolio for Student Teachers of Languages (EPOSTL) can be offered in assessment courses to make prospective teachers aware of their teaching progress. By using portfolios like these in pre-service, a language teacher can become a perpetual learner by himself. For the in-service EFL teachers, professional development plays a key role to improve their LAL. They need to be supported with more and more in-service trainings, conferences, workshops etc. No matter how much they have been trained in theory, they cannot achieve success in education unless they measure what they really teach effectively. As mentioned above, they also need sufficient time, smaller class size and less work load to apply various assessment concepts and procedures appropriately.

\section{References}

Aksu Ataç, B. (2012). Foreign Language Teachers' Attitude toward Authentic Assessment in Language. The Journal of Language and Linguistic Studies, 8(2), 0-19. Retrieved from https://dergipark.org.tr/tr/pub/jlls/issue/9936/122911.

Arias, C., \& Maturana, L. (2005). Evaluación en lenguas extranjeras: discursos y prácticas [Assessment in language teaching: Discourse and practices]. Íkala, Revista de Lenguajey Cultura, 10(1) 63-91. 
Bailey, K. M., \& Brown, J. D. (1996). Language testing courses: What are they? In A. Cumming \& R. Berwick (Eds.), Validation in language testing (pp. 236-256). Clevedon, UK: Multilingual Matters.

Berry, V., Sheehan, S., \& Munro, S. (2019, April). What does language assessment literacy mean to teachers? ELT Journal, 73(2), 113-123. doi:10.1093/elt/ccy055

Borg, S. (2006). The distinctive characteristics of foreign language teachers. Language Teaching Research, 10(1), 3-31.

Brown, J. D. \& Bailey, K. M. (2008). Language testing courses: What are they in 2007? Language Testing, 25(3), 349-383. doi: 10.1177/0265532208090157

Büyükkarcı, K. (2014). Assessment beliefs and practices of language teachers in primary education. International Journal of Instruction, 7(1), 107-120.

Büyükkarcı, K. (2016). Identifying the areas for English language teacher development: A study of assessment literacy. Pegem Ĕ̆itim ve Öğretim Dergisi, 6(3), 333-346.

Campbell, C., Murphy, J. A. \& Holt, J. K. (2002). Psychometric analysis of an assessment literacy instrument: Applicability to pre-service teachers. Paper presented at the annual meeting of the Mid-Western Educational Research Association, Columbus, $\mathrm{OH}$.

Chan, Y-C. (2008). Elementary school EFL teachers' beliefs and practices of multiple assessments. Reflections on English Language Teaching, 7(1), 37-62.

Cheng, L., Rogers, T., \& Hu, H. (2004). ESL/EFL instructors' classroom assessment practices: purposes, methods, and procedures. Language Testing, 21(3), 360-389. http://dx.doi.org/10.1191/0265532204lt2880a.

Coombe, C. A. 1., Folse, K. S., \& Hubley, N. J. (2007). A practical guide to assessing English language learners. Ann Arbor, Mich.: University of Michigan.

Darling-Hammond, L. (2008). The case for university-based teacher education. In M. Cochran-Smith, K. E. Demers, S. Feiman-Nemser, \& D. J. McIntyre (Eds.), Handbook of research on teacher education: Enduring questions in changing contexts $\left(3^{\text {rd }}\right.$ edition), 333 - 346. New York: Routledge and Association of Teacher Educators.

Davidheiser, S. (2013). Identifying Areas for High School Teacher Development: A Study of Assessment Literacy in the Central Bucks School District. Drexel University, Philadelphia, Pennsylvania.

Davies, A. (2008). Textbook trends in teaching language testing. Language Testing, 25, 327-348.

Díaz, C., Alarcón, P., \& Ortiz, M. (2012). El profesor de inglés: sus creencias sobre la evaluación de la lengua inglesa en los niveles primario, secundario y terciario [The English teacher: His beliefs about English language assessment at primary, secondary and tertiary levels]. Íkala, Revista de Lenguaje y Cultura, 17(1), 15-26.

Frodden, M., Restrepo, M., \& Maturana, L. (2004). Analysis of assessment instruments used in foreign language teaching. Íkala, Revista de Lenguaje y Cultura, 9(1), 171201. 
Fulcher, G. (2010). Practical language testing. London: Hodder Education.

Fulcher, G. (2012). Assessment literacy for the language classroom. Language Assessment Quarterly, 9(2), 113-132.

Giraldo, F. (2019). Language assessment practices and beliefs: Implications for language assessment literacy. HOW, 26(1), 35-61. https://doi.org/10.19183/how.26.1.481

Gönen, K. \& Akbarov, A. (2015). Instructors' principles and practices of classroom based language assessment in higher education in Turkey. Journal of European Education, 5(3), 28-38.

Guerin, E. M. C. (2010). Initial findings from a pilot Italian study of foreign language teachers' stated language assessment knowledge-base and needs. Paper presented at the Lancaster University Postgraduate Conference in Linguistics \& Language Teaching, Lancaster, the United Kingdom.

Hakim, B. (2015). English language teachers' ideology of ELT assessment literacy. International Journal of Education \& Literacy Studies, 3(4), 42-48.

Han, T. \& Kaya, H. İ. (2014). Turkish EFL teachers' assessment preferences and practices in the context of constructivist instruction. Journal of Studies in Education, 4(1), 77-93.

Hatipoğlu, Ç. (2010, Winter). Summative evaluation of an English language testing and evaluation course for future English language teachers in Turkey. ELTED, 13, 4051.

Hatipoğlu, C.. (2015a). English language testing and evaluation (ELTE) training in Turkey: Expectations and needs of pre-service English language teachers. ELT Research Journal, 4(2), 111-128.

Hatipoğlu, Ç. (2015b, May). Diversity in language testing and assessment literacy of language teachers in Turkey. Paper presented at the 3 rd ULEAD Congress, International Congress on Applied Linguistics: Current Issues in Applied Linguistics, Çanakkale, Turkey.

Hatipoğlu, Ç., \& Erçetin, G. (2016). Türkiye'de yabancı dilde ölçme ve değerlendirme eğitiminin geçmişi ve bugünü. In S. Akcan \& Y. Bayyurt (Eds), 3. ulusal yabancı dil eğitimi kurultayı: Türkiye'deki yabancı dil eğitimi üzerine görüş ve düşünceler 23-24 Ekim 2014, konferanstan seçkiler, 72-89. İstanbul, Turkey: Boğaziçi University.

Hamp-Lyons, L. (2017). Language assessment literacy for language-oriented assessment. Papers in Language Testing and Assessment, 6(1), 88-111.

Hasselgreen, A., Carlsen, C., \& Helness, H. (2004). European Survey of Language Testing and Assessment Needs. Retrieved from: www.ealta.eu.org/resources.htm

Herrera, L., \& Macías, D. (2015). A call for language assessment literacy in the education and development of Teachers of English as a foreign language. Colombian Applied Linguistics Journal, 17(2),

https://doi.org/10.14483/udistrital.jour.calj.2015.2.a09. 
Hidri, S. (2015). Conceptions of assessment: Investigating what assessment means to secondary and university teachers. Arab Journal of Applied Linguistics, 1(1), 19-43.

Inbar-Lourie, 0. (2008). Constructing a language assessment knowledge base: A focus on language assessment courses. Language Testing, 25 (3), 385 - 402.

Jannati, S. (2015). ELT teachers' language assessment literacy: Perceptions and practices. The International Journal of Research in Teacher Education, 6(2), 2637.

Jeong, H. (2013). Defining assessment literacy: Is it different for language testers and non-language testers? Language Testing, 30(3), 345-362. https://doi.org/10.1177/0265532213480334.

Jin, Y. (2010). The place of language testing and assessment in the professional preparation of foreign language teachers in China. Language Testing, 27(4), 555584. https://doi.org/10.1177/0265532209351431.

Kavakl,, N., \& Arslan, S. (2019). Towards a continuum from know-how to show-how for developing EFL student-teachers" assessment literacy. International Online Journal of Education and Teaching (IOJET), 6(1). 1261-1270.

Kiomrs, R., Abdolmehdi, R., \& Naser, R. (2011). On the interaction of test washback and teacher assessment literacy: The case of Iranian EFL secondary school teachers. English Language Testing, 4(1), 156-161.

Kırkgöz, Y. \& Ağçam, R. (2012). Investigating the written assessment practices of Turkish teachers of English at primary education. The Journal of Language and Linguistic Studies, 8(2), 119-136.

Köksal, D. (2004). Assessing teachers' testing skills in ELT and enhancing their professional development through distance learning on the net. Turkish Online Journal of Distance Education-TOJDE, 5(1). Retrieved from https://dergipark.org.tr/tr/pub/tojde/issue/16931/176755

Lam, R. (2015). Language assessment training in Hong Kong: Implications for language assessment literacy. Language Testing, 32(2), 169-197. doi: 10.1177/0265532214554321.

Lambert, D. \& Lines D. (2000). Understanding Assessment: Purpose Perceptions, Practices. London: Routledge Falmer.

Leaph, K., Channy, M., \& Chan, N. K. (2015). Cambodian ELT university practitioners' use of standardized tests for practice and assessment. Language Education in Asia, 6(1), 4-16.

López, A., \& Bernal, R. (2009). Language testing in Colombia: A call for more teacher education and teacher training in language assessment. Profile: Issues in Teachers' Professional Development, 11(2), 55-70.

Mahapatra, S. K. (2016). Tracking the development of teachers' language assessment literacy: A case study. In G. Pickering \& P. Gunashekar (Eds.), Ensuring quality in English language teacher education,106-114. New Delhi, India: British Council. 
Malone, M. E. (2013). The essentials of assessment literacy: contrasts between testers and users. Language Testing, 30(3), 329-344.

Mede, E., \& Atay, D. (2017). English language teachers' assessment literacy: The Turkish context. Ankara Üniversitesi TÖMER Dil Dergisi, 168(1), 43-60.

Mertler, C. A. \& Campbell, C. (2005, April). Measuring teachers' knowledge \& application of classroom assessment concepts: Development of the Assessment Literacy Inventory. Paper presented at the annual meeting of the American Educational Research Association, Montreal, Quebec, Canada.

Montee, M., Bach, A., Donovan, A., \& Thompson, L. (2013, Spring). LCTL teachers' assessment knowledge and practices: An exploratory study. Journal of the National Council of Less Commonly Taught Languages, 14, 1-32.

Muhammad, F. H. N. \& Bardakçı, M. (2019). Iraqi EFL Teachers' Assessment Literacy: Perceptions and Practices. Arab World English Journal, 10 (2) 420-430. doi: https://dx.doi.org/10.24093/awej/vol10no2.33

Muñoz, A., Palacio, M., \& Escobar, L. (2012). Teachers' beliefs about assessment in an EFL context in Colombia. Profile: Issues in Teachers' Professional Development, 14(1), 143-158.

Nier, V. C., Donovan, A. E., \& Malone, M. E. (2013). Promoting assessment literacy for language instructors through an online course. Retrieved from http://www.cal.org/ecolt/pdfs/AB Poster 10-21-2013 FINAL.pdf

Ölmezer-Öztürk, E., \& Aydın, B. (2019). Investigating language assessment knowledge of EFL teachers. Hacettepe University Journal of Education, 34(3), 602-620. doi:10.16986/HUJE.2018043465

Öz, H. (2014). Turkish teachers' practices for assessment for learning in the English as a foreign language classroom. Journal of Language Teaching and Research, 5(4), 775785.

Öz, S. \& Atay, D. (2017). Turkish EFL instructors' in-class language assessment literacy: Perceptions and practices. ELT Research Journal, 6(1), 25-44.

Perry, M. (2013). Teacher and Principal Assessment Literacy (Doctoral dissertation). Retrieved from https://scholarworks.umt.edu/cgi/viewcontent.cgi?article=2410\&context=etd

Plake, B. S. (1993). Teacher assessment literacy: Teachers' competencies in the educational assessment of students. Mid-Western Educational Researcher, 6(2), 21-27.

Plake, B. S., Impara, J. C. \& Fager, J. J. (1993). Assessment Competencies of Teachers: A National Survey. Educational Measurement: Issues and Practice, 12(4), 10-12. http://dx.doi.org/10.1111/j.1745-3992.1993.tb00548.x

Popham, W. J. (2011). Assessment literacy overlooked: A teacher educator's confession. The Teacher Educator, 46(4), 265-273. 
Price, M., Rust, C., O’Donovan, B., Handley, K. and Bryant, R. (2012). Assessment Literacy: The Foundation for Improving Student Learning. Oxford: The Oxford Centre for Staff and Learning Development.

Purpura, J. E. (2016). Second and foreign language assessment. The Modern Language Journal, 100, 190-208.

Razavipour, K. (2014). Assessing assessment literacy: Insights from a high-stakes test. RALS, 4(1), 111-131.

Rea-Dickins, P. (2006). Currents and eddies in the discourse of assessment: A learning focused interpretation. International Journal of Applied Linguistics, 16(2), 164-188.

Riestenberg, K., Silvio, F. D., Donovan, A., \& Malone, M. E. (2010, Fall). Development of a computer-based workshop to foster language assessment literacy. Journal of the National Council of Less Commonly Taught Languages, 9, 21-42.

Rogers, W. T., Cheng, L., \& Hu, H. (2007). ESL/EFL instructors' beliefs about assessment and evaluation. Canadian and International Education/Education canadienne at internationale, 36(1), 39-61.

Semiz, Ö. \& Odabaş, K. (2016, June). Turkish EFL teachers' familiarity of and perceived needs for language testing and assessment literacy. Proceeding of the 3rd international linguistics and language studies conference, İstanbul, Turkey. Retrieved from https://docs.wixstatic.com/ugd/bac820 2c683311d65a478f9b10ee6dfbd1020d.p $\underline{\mathrm{df}}$

Şahin, S. (2015, May). Language testing and assessment (LTA) literacy of high school English language teachers in Turkey. Paper presented at the $3^{\text {rd }}$ ULEAD Congress, International Congress on Applied Linguistics: Current Issues in Applied Linguistics, Çanakkale, Turkey.

Şahin, S. (2019). An analysis of English language testing and evaluation course in English language teacher education programs in Turkey: developing language assessment literacy of pre-service EFL teachers (Unpublished doctoral dissertation). Middle East Technical University, Ankara, Turkey.

Sarıçoban, A. (2011). A study on the English language teachers' preparation of tests. Hacettepe Üniversitesi Eğitim Fakültesi Dergisi, 41, 398-410.

Sarıyıldı, G. (2018). A study into language assessment literacy of preservice English as a foreign language teachers in Turkish context (Unpublished master's thesis). Hacettepe University, Ankara, Turkey.

Schulman, L.S. (1987). Knowledge and teaching: Foundations of the new reform. Harvard Educational Review, 57(1), 1-22.

Sellan, R. (2017). Developing language assessment literacy in Singapore: How teachers broaden English language learning by expanding assessment constructs. Papers in Language Testing and Assessment, 6(1), 64-87. 
Sevimel Şahin, A. (2019). Exploring foreign language assessment literacy of pre-service English language teachers. (Doctoral dissertation). Anadolu University, Eskişehir, Turkey.

Shohamy, E., Inbar-Lourie, O., \& Poehner, M. (2008). Investigating assessment perceptions and practices in the advanced foreign language classroom (Report No. 1108). University Park, PA: Center for Advanced Language Proficiency Education and Research.

Talib, R., Kamsah, M. Z., Ghafar, M. N. A., Zakaria, M. A. Z. M., \& Naim, H. A. (2013). Tassess: Assessment literacy for Malaysian teachers. Paper presented at the International Conference on Assessment for Higher Education Across Domains and Skills, Kuala Lumpur.

Taylor, L. (2009). Developing assessment literacy. Annual Review of Applied Linguistics, 29, 21-36.

Tsagari, D. \& Vogt, K. (2017). Assessment literacy of foreign language teachers around Europe: Research, challenges and future prospects. Papers in Language Testing and Assessment, 6(1), 41-63.

Volante, L., \& Fazio, X. (2007). Exploring teacher candidates' assessment literacy: Implications for teacher education reform and professional development. Canadian Journal of Education, 30(3), 749-770. https://doi.org/10.2307/20466661.

Vogt, K., Guerin, E., Sahinkarakas, S., Pavlou, P., Tsagari, D., \& Afiri, Q. (2008). Assessment literacy of foreign language teachers in Europe - current trends and future perspectives. Paper presented at the $5^{\text {th }}$ EALTA Conference, Athens, Greece.

Vogt, K., \& Tsagari, D. (2014). Assessment literacy of foreign language teachers: Findings of a European study. Language Assessment Quarterly, 11(4), 374-392.

Walters, F. S. (2010). Cultivating assessment literacy: Standards evaluation through language-test specification reverse engineering. Language Assessment Quarterly, 7(4), 317-342. doi: 10.1080/15434303.2010.516042

Xu, Y. \& Brown, G. T. L. (2017). University English teacher assessment literacy: A surveytest report from China. Papers in Language Testing and Assessment, 6(1), 133-158.

Yamtim, V., \& Wongwanich, S. (2013). A Study of Classroom Assessment Literacy of Primary School Teachers. Procedia- Social and Behavioral Sciences, 116, 29983004. http://dx.doi.org/10.1016/i.sbspro.2014.01.696

Yan, X., Zhang, C., \& Fan, J. J. (2018). “Assessment knowledge is important, but...”: How contextual and experiential factors mediate assessment practice and training needs of language teachers. System, 74, 158-168.

Yastıbaş, A. E. (2018). Language assessment literacy of Turkish EFL instructors: a multiple-case study (Unpublished doctoral dissertation). Atatürk University, Erzurum, Turkey.

Yetkin, C. (2015). An investigation on ELT teacher candidates' assessment literacy (Unpublished master's thesis). Çă̆ University, Mersin, Turkey. 